\title{
A Case Study of Moral Disengagement on the Juvenile Sex Offenders
}

\author{
Dessi Christanti \\ Psychology Faculty, Widya Mandala Catholic University, \\ Jl. Kalisari Selatan I Pakuwon City Surabaya 60I I Indonesia \\ Student of Doctoral Programme Psychology Faculty, Airlangga University, \\ Jl. Airlangga 4-6 Surabaya 60286 Indonesia \\ E-mail: dessi@ukwms.ac.id \\ Suryanto \\ Psychology Faculty, Airlangga University, \\ Jl. Airlangga 4-6 Surabaya 60286 Indonesia \\ E-mail: suryanto@psikologi.unair.ac.id \\ Muhammad Ghazali Bagus Ani Putra \\ PT. Sekar Laut, Tbk., \\ Jl. lenggolo, Sidoario 61219 Indonesia \\ E-mail: bagusaniputra@sekarlaut.com
}

\begin{abstract}
This study aims to explore the moral disengagement in juvenile sex offenders and how their social environment relates to moral disengagement. Cognitive processes have a role in encouraging adolescents to fornicate a girl. The theory of moral disengagement can explain why adolescents do sexual offenses. This research used a qualitative method of a case study. The number of participants was seven adolescents aged 16-18 years and had been found guilty of forcibly by the court. The interview method was used to collect the data. The results showed that the juvenile sex offenders used seven forms of moral disengagement of Bandura's theory: moral justification, euphemistic labeling, displacement of responsibility, diffusion of responsibility, distortion of consequences, dehumanization, and attribution of blame. The result also showed that juvenile sex offenders used active avoidance to minimize their guilty feeling. This was a different form of early moral disengagement form of Bandura. The social environments identified in this research were the family condition, permissive environmental, peer group, pornographic exposure, lack of appreciation of religion, and the absence of adverse reaction from the victim.
\end{abstract}

Keywords: moral disengagement, The juvenile sex offenders, social environment, case study 


\section{Introduction}

Sexual crime against women is still occurring in Indonesia. According to the Indonesian Women's National Commission, in 2018, sexual crime against women had increased by $14 \%$ from the previous year (Komnas Perempuan, 2019). The victim of sexual crime is not only adult women but also young girls. From the offender side, adolescent boys can also be a sex offender. Juvenile sex offenders usually do their first sexual crimes at the age of 12-7 years old (Schuler, 2014). This phenomenon, which has negative impacts, should be suppressed. One way to overcome this phenomenon is to find the cause of juvenile sex offenders. Through research, the answers to why adolescents commit a sexual crime can be found. One of them is this study that traced the beliefs of juvenile sexual offenders. The results of this research can be used to design prevention and rehabilitation programs based on the cognitive aspect of adolescent boys so that they do not commit a sexual crime.

A the juvenile sex offenders can be defined as an adolescent who has been convicted by the court of having committed sexual crimes (Barbaree \& Marshal, 2006). Sexual crime consists of sexual violence itself such as rape or sexual violence. Other forms of sexual crime can take the form of other crimes that have a component of sexual crimes such as murder accompanied by rape (Barbaree \& Marshal, 2006). According to the previous study, the forms of sexual crimes that the juvenile sex offenders have themselves been exposed were physically abused, sexually abused, emotionally abused and combination of physically, sexually and emotionally abused (Naidoo \& Sewpaul, 20l4).

Several studies have been conducted to investigate why adolescent commits sexual crimes. Some evidence showed that exposure to pornography (Bleakley, Hennessy, Fishbein, \& Jordan, 201 I; Sandvik, Nesset, Berg, \& Søndenaa, 2017; Schuler, 2014), experience of sexual violence (Plummer \& Cossins, 2018; Wegner, Abbey, Pierce, Pegram, \& Woerner, 20I5), characteristic of victim (Jewkes et al., 20I2; McCann \& Lussier, 2008), family disharmony (Knox, 20I4; McCuish, Lussier, \& Corrado, 2015) weak parental supervision (Naidoo \& Sewpaul, 2014), alcohol (Hunter, Figueredo, Malamuth, \& Becker, 2003; Wegner et al., 20I5) and environment 
or situation that was not conducive (Jewkes et al., 2012) were the external factors that caused adolescent committed fornication. The other factors come from the internal of an individual such as antisocial personality (McCann \& Lussier, 2008) and low interpersonal skills (Ryan, 2010). The low moral level is also often seen as the cause of adolescent committing sexual violence (Sandvik et al., 2017; Seto \& Lalumie, 2010).

Unfortunately, not many previous studies had touched on the cognitive aspect of the the juvenile sex offenders (Beech, Ward, \& Fisher, 2006). In sociocultural terms, sexual crime is seen as a manifestation of gender inequality and subordination against women. So, men only see women as sexual object (Macionis, 2009). This view based on patriarchal culture might be one of the reason or belief of juvenile sex perpetrator. They molested women without feel guilty. They know this action violate moral but they still do that action. Thus, it is necessary to know the various beliefs of the juvenile sex offenders.

The moral disengagement theory proposed by Bandura (Osofsky, Bandura, \& Zimbardo, 2005) can explain the linkage of processes within the cognitive to the behavior of the individual. Moral disengagement is a cognitive structure that is formed when an individual experiences a conflict between committing a moral offense with his or her moral guidelines (Bandura, 2004). Individuals tend to perform moral disengagement when they see themselves as doing the wrong thing (Shu, Gino, \& Bazerman, 20II). Moral disengagement will reduce the feelings of guilt in the individual so that individuals easily perform moral contradictory behavior (Bandura, Barbaranelli, \& Caprara, 1996).

There are eight ways or form to do moral disengagement. Thus eight of moral disengagements come from three aspects namely reprehensible conduct, detrimental effect, and victim (Bandura, 2016). The first three forms of moral disengagement are moral justification, palliative/advantageous comparison, and euphemistic labeling. These three forms come from reprehensible conduct. The next forms of moral disengagement are displacement of responsibility and diffusion of responsibility. These two forms come from reprehensible 
conduct and detrimental effect. The form of moral disengagement that only comes from a detrimental effect is a distortion of consequences. The last two forms are dehumanization and attribution of blame that comes from the victim aspect (Bandura, 2002, 2016).

The moral justification happens when individuals do moral justification for moral offenses. It can be said that individuals rationalize or find reasons to justify their actions (Bandura, 2016). The example of moral justification was the rationalization of soccer. They used moral justification to justify their fraud. They said that it was their responsibility to anticipate the opponent's attack even if they had to commit a minor offense. Therefore the soccer player felt innocent when committing a violation during a match (Traclet, Romand, Moret, \& Kavussanu, 20I I).

Palliative comparison/advantageous comparison has happened when an individual makes comparisons between his actions with other deeds. Through this comparison, the individual can justify his actions because what he did was judged to be more valuable, more profitable, or lighter than other moral offenses (Bandura, 2016). President United States of America, George Bush, used a palliative comparison when attacking Iraq. President Bush believed that resolving nonviolent problems was less effective than the invasion of Iraq. (Cartledge et al., 20I5)

Euphemistic labeling that is language can be used to refine unlawful acts committed by individuals. Euphemism has been used extensively to shape the perceptions of others so that real cruel acts no longer sound cruel (Bandura, 2016). Many sexual harassers used euphemistic labeling to describe and justify sexual harassment behavior. They sanitized their language as an attempt to appear "friendly" or "friendly" to the opposite sex when faced with their actions. Sexual harassers also justified their actions as merely "playing," or "joking" (Quinn, 2002)

Displacement of responsibility happens when individuals are more likely to engage in legal action when they see the behavior on the orders of others with authority. Thus the individual does not need to be responsible for the consequences of his actions (Bandura, 2016). Followers do not feel guilty when doing orders that have the potential to hurt others or violate 
morals. The followers do it on behalf of the boss's orders, so they are free from responsibility (Johnson, 2014).

Diffusion of responsibility that is the individual feels there is a blurring of responsibility; then, the individual becomes more comfortable to do negatively (Bandura, 2016). Diffusion of responsibility is a process in the minds of individuals regarding the negative consequences of behavior (Beyer, Sidarus, Bonicalzi, Haggard, \& Beyer, 2016). Negative consequences make Individuals tend to avoid responsibility, especially if the behavior is carried out in a group (Bandura, 1990b). As an example, gang members tend to avoid responsibility when committing crimes in a multicolored manner (Alleyne, Fernandes, \& Pritchard, 20I4).

Disregard or Distortion of Consequences that is another way that an individual can easily perform an inhumane act, is to ignore or minimize the consequences of his actions (Bandura, 2016). For example, soccer players who commit violations try to minimize the impact of their cheating behavior. They perceived that cheating in the soccer game is socially acceptable (Traclet et al., 20II)

Dehumanization is the way individuals perceive and respect others determines whether the individual is capable of doing inhumane deeds (Bandura, 2016). Degrading other people can be done to women, children, ethnic minorities, patients, the poor, or people with disabilities (Haslam, 2006). In the case of gang violence, gang members were able to hurt their victims because they considered the victim is inferior to them (Alleyne et al., 2014).

Attribution of blame that is blaming other people (the victim) and the environment is one way that individuals usually use when committing unlawful or moral acts (Bandura, 2016). In rape cases, the offender usually blames the victim (Strömwall, Landström, \& Alfredsson, 20I4). They blame women's appearance as the cause of rape (Wolvendale, 2016). 
The theory of moral disengagement has been used extensively to understand why individuals can commit unlawful acts that harm others. Moral disengagement positively correlates with bullying behavior (Caravita, Sijtsema, Rambaran, \& Gini, 20I4), and is positively correlated with the individual tendency to fight (Stevens \& Hardy, 20I I). Children in conflict with the law have higher moral disengagement than school children (Kiriakidis, 20I0).

The moral theory of disengagement can also be used to analyze why individuals commit sex abuse (Page \& Pina, 2015, 2018). For example, the myth of rape and the act of blaming the victim as a cause of fornication and even rape can be categorized as one of the moral mechanisms of disengagement (Bandura, 1986, 2016; Page \& Pina, 2015). So it can be concluded that moral disengagement has a vital role in facilitating and encouraging the occurrence of sex abuse.

Previously there has been researched that explains the relationship between moral disengagement with attitudes toward rape (Carroll, 2009). The study showed that male students who had high levels of moral disengagement turned out to have a positive attitude to support rape. Although using the moral theory of disengagement, but the research is limited to attitudes toward rape alone. It was not the behavior of obscenity or rape. Also, the subjects of the study were male high school students. They were not juvenile sex offenders. So, this study has not yet expressed the beliefs of juvenile sex offenders.

This moral theory of disengagement is part of the grand perspective of social cognition theory (Bandura, 1986). Behavior is a reciprocal function between the environment and the individual. Thus the moral mechanism of disengagement is also inseparable from environmental elements. Therefore it is also necessary to examine social, environmental factors that may play a role in the formation of moral disengagement in adolescent perpetrators of abuse. The social factors can be exposed to violence seen by individuals (Dhingra, Debowska, Sharratt, Hyland, \& Kolapalmer, 20I5), family (DeLisi et al., 20I4), and peer groups (Sweeten, Piquero, \& Steinberg, 2013). 
Therefore, previous studies about juvenile sex offenders have not examined the beliefs of juvenile sex offenders. The previous researches about the juvenile sex offenders emphasized more on the external factor and personality factor of the juvenile sex offenders such as having committed sexual abuse before (McCann \& Lussier, 2008), high sexual desire (Sandvik, Nesset, Berg, \& Søndenaa, 20I7), low level of moral development (Van Vugt, 20II), exposure to pornography (Naidoo \& Sewpaul, 2014; Schuler, 2014), characteristic of victim (McCann \& Lussier, 2008) and inadequate parental supervision (Naidoo \& Sewpaul, 20I4). Likewise, several studies about a sexual crime that utilized moral disengagement theory also did not reveal the forms of moral disengagement of juvenile sex offenders (Petruccelli et al., 2017). This research only showed that sex offenders had higher moral disengagement than other criminals (Petruccelli et al., 2017).

It is important to know what kind of thoughts underlie juvenile sex offenders. It is equally important to finding external factors that shape those beliefs or rationalization. Thus, this time, the study was designed to fill the gap of researching juvenile sex offenders based on the moral theory of disengagement. This current study will explore the moral disengagement of juvenile sex offenders and also identified the social environment that relates to moral disengagement.

\section{METHOD}

This research was designed as a qualitative instrumental case study. The case study is conducted to understand human interaction within a single social unit, a single instance bounded by the caseworker in the process of designing the research (Stake, 1995). The instrumental case study is selected when there is a need to make a general and comprehensive understanding of a problem by examining one case. The instrumental case study also used to promote an understanding of a specific issue. Through a separate case study, the researcher studied a case in-depth, and the context was also scrutinized (Stake, 1995). This work is an example of an instrumental case study. 
This study was conducted in the youth detention center in Blitar East Java Indonesia. Participants of this study were seven male the juvenile sex offenders. They were ranging in age between 16-18 years old. Participants came from several regions in East Java Indonesia. Participants have varied family background. Some participant had been drop-out from school.

Table I

The Data of Participants

\begin{tabular}{|c|c|c|c|}
\hline Participant & Age & Level of Education & Family background \\
\hline $\mathrm{N}$ & 16 & $\begin{array}{l}\text { Drop out during } \\
\text { Junior high school }\end{array}$ & $\begin{array}{l}\text { His Parent divorced, he lived with his father and } \\
\text { two young sisters }\end{array}$ \\
\hline A & 17 & $\begin{array}{l}\text { Drop out during } \\
\text { Junior high school }\end{array}$ & Parents died, he lived with his big brother \\
\hline $\mathrm{H}$ & 17 & $\begin{array}{l}\text { Islamic Boarding } \\
\text { School }\end{array}$ & $\begin{array}{l}\text { He lived in Islamic Boarding School and went } \\
\text { home to his parents on vacation }\end{array}$ \\
\hline $\mathrm{J}$ & 18 & $\begin{array}{l}\text { Drop out during } \\
\text { Senior high school }\end{array}$ & $\begin{array}{l}\text { He lived with his mother while his father } \\
\text { worked in Jakarta as a massage therapist }\end{array}$ \\
\hline $\mathrm{R}$ & 16 & $\begin{array}{l}\text { 3rd-grade junior high } \\
\text { school }\end{array}$ & $\begin{array}{l}\text { He lived with his grandfather while his parents } \\
\text { lived in another village }\end{array}$ \\
\hline $\mathrm{F}$ & 16 & $\begin{array}{l}\text { Drop out during } \\
\text { Senior high school }\end{array}$ & $\begin{array}{l}\text { He lived with his grandfather. His parents } \\
\text { divorced, and each had been married again. }\end{array}$ \\
\hline E & 17 & $\begin{array}{l}\text { 2nd-grade senior high } \\
\text { school }\end{array}$ & $\begin{array}{l}\text { He lived with his mother and brother. His } \\
\text { father had died. }\end{array}$ \\
\hline
\end{tabular}

Before conducting data retrieval, the researcher requested the ethical clearance to ensure that this research could be carried out ethically. The ethical clearance was obtained from the ethics committee of the university, where the researcher works. The researcher also asked about the willingness of participants to be interviewed. The participant's consent was stated through informed consent. 
Data collection used the semi-structured technique. This Technique allowed the researcher to get the answer from the participant regarding the research question or the problem under study. Interview guidance was made based on the disengagement moral theory (Bandura, 1986) to direct the interview. This interview guidance covered form of (a) moral disengagement that was used by the juvenile sex offenders and (b) social environment that develop moral disengagement. Data collection was held in January - July 2018. Interviews were recorded using a recorder device. The interview process lasted 2 to 4 times. The duration of each interview session was 45-90 minutes. This interview process depended on the situation and condition of the participant and the situation of the youth detention center.

Data analysis used the stages of data analysis from stake (1995) i.e. categorization or direct interpretation, find patterns and naturalistic generalization. The first step was to read the transcript of the interview. Researcher assisted by an assistant to make a transcript of the interview result. After reading the interview transcript, the researcher made direct interrelation and categorization by searching for a keyword or multiple keywords from the data to find meaning indicating the existence of moral disengagement of the juvenile sex offenders. Furthermore, to search for meaning or understanding of cases of the juvenile sex offenders, researchers created a pattern for consistency.

Triangulation of data was used to keep the credibility or validity of this qualitative study. Triangulation of data was used by interviewing officer of the counseling division of youth detention center. The purpose of this interview was to find out participant's background. When participants entered the youth detention center, the officer of the counseling division conducted an interview with participants. So, the interviewing officer of the counseling division was the right decision. Triangulation of data was also done by reading participants' archives. This archives contained participant's data and the chronology of the fornication committed by participants. After comparing all the data, it was concluded that the data from the officer and archives were similar to the participant's story. 
Triangulation of investigators by asking other researchers or experts to interpret the research data was also used to complete triangulation. The results of the interpretation of other researchers were then compared with the results of the interpretations of researchers. Both interpretation results were then compared and discussed.

\section{Result}

Based on the data analysis, the seven participants of this study used moral disengagement to free themselves from feelings of guilt. The forms of moral disengagement were moral justification, euphemistic labeling, displacement of responsibility, diffusion of responsibility, distortion of consequences, dehumanization, and attribution of blame. Those seven forms of moral disengagement were in accordance with the theory of moral disengagement from Bandura (1986, 2016). All participants did not use palliative comparison. They never compared their offense to other types of crime.

This study also found a new form of moral disengagement. The name was active avoidance. This form was a difference with the previous theory of moral disengagement from Bandura. Table 2 below presents the kind of moral disengagement form and an example quotation of each moral disengagement form.

Table 2

Moral Disengagement Mechanism Used by Participants and Examples of Quotation

\begin{tabular}{ll}
$\begin{array}{c}\text { Moral } \\
\text { Disengagement } \\
\text { Mechanisms }\end{array}$ & Examples of Quotation \\
\hline $\begin{array}{l}\text { Moral } \\
\text { Justification }\end{array}$ & yes I was curious about how it feels, and if not trying to have sex, it is not a man \\
& (N) \\
& Yes, mam, according to my friends, if I have a girl, but I cannot ask her to sleep \\
& together than I lose.. Having a girlfriend should be able to have sexual relations...so \\
& I get the benefit (J) \\
& Yes, ...one friend challenged another friend, told him to bring his girlfriend. Then \\
& this friend brought the girl to the group, ... and all raped her in turn. At first, I just \\
\hline
\end{tabular}


saw them, then one of my friends invited me ...then I also did it. (R)

\begin{tabular}{|c|c|}
\hline $\begin{array}{l}\text { Euphemistic } \\
\text { Labeling }\end{array}$ & Anget-Angetan (Making warm together) (N) \\
\hline $\begin{array}{l}\text { Displacement of } \\
\text { Responsibility }\end{array}$ & $\begin{array}{l}\text { yeah..if I rejected, they would not take me home and the second I would be beaten } \\
(H)\end{array}$ \\
\hline $\begin{array}{l}\text { Diffusion of } \\
\text { Responsibility }\end{array}$ & $\begin{array}{l}\text { I do not know since when there has been a habit like that, it was already there, me } \\
\text { and my friend used to do that, it became a habit, it is okay to sleep with friend's } \\
\text { girl.. sometimes even my friend told the others to sleep with his girl, especially when } \\
\text { he wants to break a relationship with his girlfriend (R) } \\
\text { But I was not the one who should be responsible, ma'am... my part was just calling } \\
\text { that girl, my friend was the person who must be responsible... The initiation was } \\
\text { from him. (J) }\end{array}$ \\
\hline $\begin{array}{l}\text { Distortion of } \\
\text { Consequences }\end{array}$ & $\begin{array}{l}\text { Yes..the girl was crying..but I did not take care of that" (N) } \\
\text { Once, there was a girl demanded my responsibility, her house was a little far away } \\
\text { from my house, I felt bad, so... then well, I broke up that girl. Done it (J). } \\
\text { The girl did not tell her parents... nothing happened. So I felt fresh, I just felt fresh, } \\
\text { moreover, nothing happened, there was nothing, there was no report, so I thought } \\
\text { that action was nothing, it was okay... it has been a long time, so yeah... I thought } \\
\text { nothing" "the victim did not report to the police... so I thought it was okay. } \\
\text { Nothing happened. So I felt okay... I felt fresh (A) } \\
\text { Yes, I paid for the food, took her for a walk. All was spent on my money, so I } \\
\text { thought I deserve to have my reward. I had been pleasing her, so it was naturally if } \\
\text { I had sex with her. It was my fee after pleasing her. (R) }\end{array}$ \\
\hline Dehumanization & $\begin{array}{l}\text { The girl is only for fun, well, just like people say that life without making love is like } \\
\text { a flowerless garden (J) } \\
\text { so with the victim's I just vented my lust (A) } \\
\text { I thought the feeling will be different when we play sex with a different girl. I have } \\
\text { never tasted my victim before }(N)\end{array}$ \\
\hline $\begin{array}{l}\text { Attribution of } \\
\text { blame }\end{array}$ & $\begin{array}{l}\text { Yeah...that girl did not seem to have shame. She was a bad girl ma'am. My victim } \\
\text { was a naughty girl. She was often taken by others boy to the hotel or villa. So for } \\
\text { me, I did not feel guilty about sleeping with her (F) } \\
\text { Sometimes there were girls who seduce men. The girls wore sexy clothes or pants } \\
\text { on the thighs. They used short pant and tight shirt. So what do you think? How } \\
\text { about that, girls was like challenging boys. Actually, girls seduced boys. They } \\
\text { attracted boys, so the boys would be interested in her. Yeah, all the same, wore } \\
\text { shorts, open clothes, used powder eyelashes, lipstick, and perfume. All those were to } \\
\text { seduce men. }(N) \\
\text { (N) }\end{array}$ \\
\hline $\begin{array}{l}\text { Active } \\
\text { Avoidance }\end{array}$ & $\begin{array}{l}\text { Yeah, just relax. Don't worry. No need to think about that. If you get bored with } \\
\text { your girlfriend, just replace it with someone else. (R). } \\
\text { Everything had been happened, there is no point in thinking about it. (R) }\end{array}$ \\
\hline
\end{tabular}


Data analysis also identified several social environments that constituted moral disengagement on the juvenile sex offenders. Social environments that shaped moral disengagement of participants were peer group, lack of family attention, lack of religiosity, permissive environment, exposure to pornography and the absence of negative reaction from victim or punishment. Table 3 below presents those social environments that formatted moral disengagement.

Table 3

Social Environment that Constituted Moral Disengagement on The juvenile sex offenders

\begin{tabular}{|c|c|}
\hline $\begin{array}{c}\text { Social } \\
\text { Environment }\end{array}$ & Examples of Quotation \\
\hline \multirow[t]{3}{*}{ Peer Group } & $\begin{array}{l}\text { I was affected by my friends, they told me that watching a porn film it's okay, so I } \\
\text { addicted to watching that kind of film, I usually go to the internet cafe and open } \\
\text { porn film link, then watch that porn video. (A) }\end{array}$ \\
\hline & $\begin{array}{l}\text { yes ... since ...... secondary school... second grade ... since I have been hanging out } \\
\text { with friends... So ... that thought was from a friend ...yeah..school taught this and } \\
\text { this, but outside of school I used to play with some friends from a different } \\
\text { school, naughty boy, they often drink alcohol, play women, so finally I ignored } \\
\text { what the teacher said (J) }\end{array}$ \\
\hline & $\begin{array}{l}\text { I better choose a friend than my girlfriend... The best friend is hard to find... it is } \\
\text { easier to find another girlfriend than loyal friend.... I was loyal to my friend. (R). }\end{array}$ \\
\hline \multirow{2}{*}{$\begin{array}{l}\text { Lack of Family } \\
\text { Attention }\end{array}$} & My Father paid more attention to my younger sisters, I felt unnoticed $(N)$ \\
\hline & $\begin{array}{l}\text { My parent was divorced and each of them had been remarriage. Now each is } \\
\text { busy with their new family. I Lived with my grandparents. Actually, my father was } \\
\text { often drunk. (F) }\end{array}$ \\
\hline \multirow[t]{2}{*}{$\begin{array}{l}\text { Lack of } \\
\text { Religiosity }\end{array}$} & $\begin{array}{l}\text { My father told me, shouted, snapped when told me to pray, but I did not pray } \\
\text { until I was hit by my father (J) }\end{array}$ \\
\hline & $\begin{array}{l}\text { My father asked me to go to the church, I did not want to. I did not go to the } \\
\text { church (N) }\end{array}$ \\
\hline $\begin{array}{l}\text { Permissive } \\
\text { Environment }\end{array}$ & $\begin{array}{l}\text { Yeah, right there, I seduced my girlfriend to have sex there. Internet rental. The } \\
\text { internet rental's guard knew some people had sex there, but he just shut up. } \\
\text { So..it was free, the internet rental was free. }(R)\end{array}$ \\
\hline
\end{tabular}


My father's friend also likes to have sex with girls. He did it at lodging around the square, near my house. I knew it, he also knew that I also did it (N)

My friend invited me to his boarding house. There is a young woman in his room. Then we drank alcohol together. We were drunk...then it happened $(E)$

Exposure to That was, uhm. Since I watched that porn video on the internet, I wanted to Pornography keep watching and watching that film again. If you have ever seen a porn video, you would be addicted to watching that video. Like playing video games, if you have ever played a video game, you would keep playing that game, just like that. You don't want to change it. (A)

The Absence But, that was okay... I came home from work and it was nothing from my of Negative Reaction from neighbors ... my neighbor was not angry to me ... yes ... ... I did not think there

Victim and was any business with $w$ anymore, it had been already done, I thought that was Punishment. normal ...... then I did not think anymore ... (A)

\section{Discussion}

Moral Disengagement

All participants indicated that they have moral disengagement about sexual behavior. This study identified seven forms of moral disengagement from Bandura and one new. Having inaccurate beliefs about the inequality of sexual relationships between men and women, viewing the woman as a sexual object and blaming the women were used widely by participants as forms of moral disengagement. Other moral disengagements were a misperception about the consequences, evading responsibility, refusing to rethink, and using euphemistic labeling. Here, the explanation of each moral disengagement of the juvenile sex offenders.

\section{Moral Justification}

Moral offenders usually have justification for their action (Bandura, 2016). In the case of the juvenile sex offenders, participant rationalized or looked for a reason to justify their immoral behavior. In the process of carrying moral justification, the sex offender made their destructive behavior can be accepted socially and personally (Wegner et al., 2015). Thus, they did not feel guilty. 
Most participants in this study stated that sexual intercourse was common in their peer group. One participant said that sexual intercourse was the result that must be obtained in dating. For some participants, their peer group was more important than a girlfriend. One participant even admitted that in his peer group if they wanted to break up their girlfriend, they would ask a friend to sleep with his girlfriend. So they could use this reason to break up his girlfriend.

"They were my hang out friends. They told me that it was okay to have sex with a girl. All used to do" (J).

"Yes mam, according to my friends, if I have a girl but I can't ask her to sleep together than I loss.. Having a girlfriend should be able to have sexual relation... so I get the benefit" (J).

"Once, I had three girlfriends. Each had a different function. One person was for money. I used her money. The other person for that... If I wanted to have sex, I went to her house. The last person was to accompany me out on Saturday night. ..... but actually, I have slept already with all of them" (R)

"The girlfriend that I used to take her on Saturday night, I took her to my friends. Then I told my friends, you can fuck her... because I wanted to break her up" (R).

Inaccurate belief about the inequality of sexual relationships between men and women became a source of moral justification on juvenile sex offenders. The views of the participant are in line with the previous study about men's motivation to abuse women. According to this previous study, $51 \%$ of the prisoner in sexual abuse cases describes women as the sexual object whose function is to serve men's sexual desire (Beech, Ward, \& Fisher, 2006). In a patriarchal culture, Gender inequality is usually experienced by women (Brahmana, Suryanto, \& Bagong, 2018). Gender role inequality serves to strengthen the social ties of men and build a collective masculine identity (Quinn, 2002). Harassing women sexually is considered a form of conformity of men to masculine values (Bowes-Sperry \& O'Leary-Kelly, 20I4). Juvenile sex offenders then imitated this view. This view then became moral justification. It was in accordance with the participant statement that if he did not dare to have sexual intercourse, then he was considered not a man. 
"Yes I was curious about how it feels, and if not trying to have sex, it is not a man" (N)

In addition to views that demean women and loyalty to groups often become the justification for the adolescent to do sexual abuse (Page \& Pina, 2015). Adolescent usually wants to be accepted by their peers. This situation might encourage the adolescent to conform to their group norms about treating their girlfriends (Bowes-Sperry \& O'Leary-Kelly, 20I4).

\section{Euphemistic Labeling}

Euphemism has been used widely to shape others' perceptions so that cruel actions no longer sound cruel and at the same time, reduce individual responsibility for their actions (Bandura, 2002, 2016). In this study, only one participant used euphemistic labeling. The rest said that they never used a particular term to replace the terms of sexual abuse. The term used by the participant was the Javanese language, "anget-angetan". This word means to warm one another. "Anget-angetan" sounds more subtle than sexual intercourse. Sexual harasser usually uses smoother terms as their attempt to reduce the actual meaning of their action so that they can do it comfortably (Page \& Pina, 2015).

\section{Displacement of responsibility}

Moral control will function well if an individual knows he is involved in negative behavior that has damage impact, but if an individual thought he was just carrying out the orders of others, the individual would feel free to commit moral violation (Bandura, 2002; White \& Bandura, 2009). In this study, one participant admitted that he was forced to rape the victim. The other perpetrator of fornication would beat him if he did not do what they said.

"Initially, I was just waiting in front of a tofu factory. However, then, they told me to come in. Then, they forced me to fuck the victim. If, I did not do it, I was threatened that I would be beaten and not be taken home. I saw, my friend's big brother agreed, so I finally did it instead of being beaten" $(\mathrm{H})$.

Adolescents can experience pressure or coercion from their friend to commit criminal acts. Coercion and threats can force an individual to do what they are told (Esiri, 2016). This 
situation makes adolescent maintain their own safety. Participant $\mathrm{H}$ said that reason made him feel free of responsibility so he could do sexual abuse.

\section{Diffusion of responsibility}

Individuals can commit sexual abuse without feeling guilty because there is a blur of responsibility (Page \& Pina, 2015). Diffusion of responsibility occurs because of job differences of several subgroups, group decision making, and habits (Bandura, 2016; Bandura et al., 1996). The result of this study showed that most participants engaged diffusion of responsibility as a moral disengagement mechanism. These participants said that another friend should be responsible. They also said that they were used to do fornication, so they did not feel guilty.

Diffusion of responsibility is a process in an individual mind about the consideration of behavior. If the consequences are negative, the individual tends to avoid responsibility especially if the detrimental behavior is carried out in the crowd (Beyer, Sidarus, Bonicalzi, \& Haggard, 2016). The role of control over moral become weak indeed if the individual feels exposed to the obscurity of responsibility for violating moral (Bandura, 1990, 2016; Bandura et al., 1996). In group crime, each actor considers another actor to be more responsible.

"But I was not the one who should be responsible, ma'am, my part was just calling that girl, my friend was the person who must be responsible.. The initiation was from him." (J)

" $H$ (one of R's friend) was the one who was wrong because he was the one who invited" (R).

Related to habits, when individual often does negative behavior, individual gradually will assume that negative behavior is reasonable. The habit is a behavior that tends to use a little cognitive process because behavior is often done (Wood, Quinn, \& Kashy, 2002).

"I do not know since when there has been a habit like that, it was already there, me and my friend used to do that, it became a habit, it is okay to sleep with friend's girl. Sometimes even my friend told the others to sleep with his girl, especially when he wants to break a relationship with his girlfriend" (R) "It was a habit, when I had a girlfriend, I definitely did it. So I considered it was natural." (N) 
The repetition of negative behavior finally makes the individual no longer feel guilty. Some participants claimed they used to have sex, so they were no longer felt guilty. Even they raped or forced a girl to have sex, and they were not felt guilty (Wood, Quinn, \& Kashy, 2002).

\section{Distortion of consequences}

Individuals can ignore or reduce the negative impact on the victim. Individuals can also stay away from the victim so they do not need to see the suffering of the victim (Bandura, 2016). In this study, the result showed that most participants used this mechanism to reduce their guilty feeling.

In the case of fornication, distortion of consequences occurs because the offender could not place himself in another person's position (Ryan, 2010). So the perpetrator fails to recognize the negative impact that is experienced by the victim (Leary-kelly \& Bowes-sperry, 200I). This happened to the participants. They ignored the negative impact on the victim. They just thought that as long as they were happy, they would do what they want. Participants only thought about themselves. They did not care about the victim.

Yes. That girl was crying, but I did not take care of that" (N)

"Yeah, I could not bear it, but how?, In my mind, I did want to care... I did not care of that, whatever." (N)

"Once, there was a girl who demanded my responsibility, and her house was a little far away from my house, I felt bad, so... then well, I broke up that girl. It was done." (J).

Interestingly, this result of the study also showed a different type of distortion of consequences. This type was a little bit different from the previous explanation of the distortion of consequences by Bandura. Some participants said that they did not feel guilty because there was no negative reaction from the victim or the victim's family or even from the law after abusing the victim. So the absence of a negative reaction from the victim made participants thinking that their behavior was a commonplace 
"The girl did not tell her parents... nothing happened. So I felt fresh, I just felt fresh. Moreover, nothing happened, there was nothing, there was no report, so I thought that action was nothing, it was okay... it has been a long time, so yeah... I thought nothing" (A)

"The victim did not report to the police... so I thought it was okay. Nothing happened. So I felt okay... I felt fresh' (A)

Beside did not feel guilty because of no negative reaction from the victim; participants also had a false assumption about the fornication on the victim. They consider that obscenity was a consequence of what they had given to women. They bought the victim something or took the victim for a walk. So they thought that sexual intercourse with the victim was a reward that they deserved to have it

"Yes, I paid for the food, took her for a walk. All was spent on my money, so I thought I deserve to have my reward. I had pleased her, so it was naturally if I had sex with her. It was my fee after pleasing her." (R)

“The girl did not protest, because after doing that, the girl was take care of'(N).

In an intimate relationship, sometimes individuals desire to get some benefits from the relationship (Darfiyanti \& Putra, 2012). So participants in this study believed that their relationship with the victim was a kind of reciprocal relationship. According to participants, the victim also got the benefit of being invited to take a walk, and she might also enjoy a sexual relationship. The juvenile sex offenders can indeed experience mistake perception of the victim. They assumed the victim gets a pleasure even though she is forced to have sexual intercourse (Page \& Pina, 2015, 2018). So, in this case, juvenile sex offenders had benefited from their immoral actions; they fulfilled their sexual desire. Unfortunately, the way to meet this sexual desire was not following society's norm. Juvenile sex offenders then used moral disengagement to overcome guilt. If an individual gets high personal benefit from immoral action, an individual tends to make a moral disengagement (Kish-Gephart, Detert, Treviño, Baker, \& Martin, 20I4). 


\section{Dehumanization}

Dehumanization occurs in daily life. This comes from a social cognitive process (Haslam, 2006). In the case of the juvenile sex offenders, women are seen as a sexual object. They think that the existence of women is to please their sexual desires. This happened to the participants in this study. They thought women as a sexual object to pleasure them. They could throw away their girlfriend easily when they bored.

The girl is only for fun, well, just like people say that life without making love is like a flowerless garden (J).

"So with the victim's I just vented my lust" (A)

"I thought the feeling will be different when we play sex with a different girl. I have never tasted my victim before" (N)

Regarding the victim as a sexual object is one way to get rid of guilty feeling. As Bandura stated, assuming that the victim lacks quality as a person, an individual commits crimes against the victim easily (Bandura, 1986, 2016). Many aspects of society related to sexuality reflect the male domination of women. Pornography, prostitution, the role of women as a sexual object in film and so on are the reflection of the view of people who demean women (Macionis, 2009). From social cognitive theory, we know that individual can learn and adopt norm from the environment (Bandura, 1986). So, the juvenile sex offenders may learn this view that demean women in society. This result supported the previous study about seeing women as a sexual object. In a previous study, it was found that in male, there was a positive correlation between women objectification with a tendency to commit sexual violence (Galdi, Maass, \& Cadinu, $2014)$.

\section{Attribution of blame}

Blaming the victim or environment is a classic strategy used by the sexual perpetrator. They often say that they are provoked by the victim behavior or appearance so they commit sexual assault (Bandura, 2002). This cognitive strategy makes sexual perpetrator do not feel guilty. 
This classic strategy also used by participants in this study. The participant said that they were provoked by the women appearance. Participants also believed that their victims were naughty girls, so it was okay to abuse that kind of girl sexually. So according to participants, the victim was also wrong.

"Yeah...that girl did not seem to have shame. She was a bad girl, ma'am. My victim was a naughty girl. Other boys often took her to the hotel or villa. So for me, I did not feel guilty about sleeping with her" $(F)$.

"Sometimes, there were girls who seduce men. The girls wore sexy clothes or pants on the thighs. They used short pants and a tight shirt. So what do you think? How about that, girls were like challenging boys. Actually, girls seduced boys. They attracted boys so that the boys would be interested in her. Yeah, all the same, wore shorts, open clothes, used powder eyelashes, lipstick, and perfume. All those were to seduce men." (N)

"The girl was also drunk, and she was a naughty girl" (E).

"I was drunk and there was a girl in the room, causing lust. It was natural" (E).

One of the myths of rape is the victim is not completely free from mistakes. Women also have a part in sexual abuse through the way they dress and behave. Women are guilty because they fail to prevent men from committing sexual abuse (Page, Pina, \& Giner-Sorolla, 2016). Criminals often avoid being held accountable for their actions by blaming the victim or the environment. They said that they only reacted to the victim's behavior. The actor of sex perpetrators tended to assume that the victim was wrong (Grubb \& Turner, 2012). The result of previous research also indicated the same thing. The participant in the previous research, both men and women, blamed the victim of sexual abuse. However, compared to women participants, more men participants tended to blame the victim (Stepanova, 2017).

\section{Active avoidance}

This term was used to describe the participant's refusal to rethink his destructive action. Some participants said that the action had occurred so that it did not need to be rethought. This term is not found in the original theory of Bandura. The way of this thinking can make participants feel free from guilty. Refusing to rethink their detrimental action was a participant way to 
remain comfortable. They knew they had violated moral. Then, participants experience cognitive dissonance. Participants overcame this uncomfortable situation by refusing to rethink their action.

"Yeah, just relax. Don't worry. No need to think about that. If you get bored with your girlfriend, just replace it with someone else." (R).

"Everything had happened; there was no point in thinking about it." (R)

"After having sex with a girl, I went to have fun. There was nothing to think about. Life is made easy. No need to think right or wrong, so I did not need to feel sorry." (J)

This finding was consistent with the previous study about cheating behavior. After cheating, individuals had a motivation to forget information that reminded them of the fraud they had committed (Shu \& Gino, 20I2). This study was also in line with another previous study on meat consumption habits. When participants in the previous study were asked about the impact of meat consumption habits, they refused to think about that. They avoided discussing the impact because that activity made them uncomfortable (Graca, Calheiros, \& OLiveira, 20I4). In the current study, participants did want to forget the things that reminded them of fornication they had done.

\section{Social environment that constituted moral disengagement}

Moral disengagement does not arise, just like that. The social environment has contributed to the formation of moral disengagement. Data from seven participants illustrated that through their environment, they adopted beliefs or perceptions that make moral in disengagement. The finding of social environments that constituted moral disengagement on this stud was:

\section{Peer group}

The main factor that most played a role in the formation of moral disengagement, according to participants, was the peer group. Participants acknowledged they were closer to friends than family. They were quicker and easier to accept friends' opinions than religious teachings or 
parental advice. Friends or peer groups made adolescents have a wrong understanding of sexual relationships.

I was affected by my friends, they told me that watching a porn film it's okay, so I addicted to watching that kind of film, I usually go to the internet cafe and open porn film link, then watch that porn video. (A)

Yes... since ...... secondary school... second grade ... since I have been hanging out with friends... So ... that thought was from a friend ...yeah, school taught this and that, but outside of school I used to play with some friends from a different school, naughty boy, they often drink alcohol, play women, so finally I ignored what the teacher said (J)

Peers were the dominant factor in shaping the moral disengagement in this study. Participants spent more time with friends than with their families. Adolescents tend to do conformity in peer groups (Caravita et al., 2014). So in juvenile sex offenders, the actors adopt beliefs or misconceptions about inter-gender relationships from peer groups. They commit fornication because of encouragement from friends. This situation may also encourage adolescent perpetrators to do the same or conformity in the way their group treats their female friends (Leary-kelly \& Bowes-sperry, 200I). These teenagers also have the belief that friendship or fraternity in a group is more important than a boyfriend. For them, a girlfriend was easier to find again that the best friend. Loyalty to groups is often the basis of justification for the juvenile sex offenders for immoral acts they commit (Page et al., 2016).

\section{Lack of family attention}

Family is the basis of individual moral formation. If the family is not harmonious, individuals usually tend to prefer to hang out with friends. In this study, six participants came from families that were not conducive. Parents of participant $\mathrm{N}$ and participant $\mathrm{F}$ were divorced. Participant J lived with his mother while his father worked in another city. Since both of his parents died, participant $A$ was taken care of by his brother. Participants $R$ lived with his grandparents, while his parents lived in another village. Participants $E$ lived with his mother and brother since his father died. His mom had an affair with another man. Such family background caused participants to be easily influenced by peers. They finally committed sexual abuse. 
“My father paid more attention to my younger sisters, I felt unnoticed' (N)

"My parent was divorced, and each of them had been remarriage. Now each is busy with their new family. I Lived with my grandparents. Actually, my father was often drunk.” (F)

The sexual perpetrators usually are raised in families that are not conducive or from damage families (Arslan, Demirkiran, Ramazan, Zeren, \& Kokacya, 2016)., for example single parents with the absence of father (Knox, 2014) so that individuals do not have a role model about how to act like men (Davids, Londt, \& Wilson, 20I5). Family disharmony has reduced parental supervision. Lack of parental supervision makes adolescent free to get along with peers who are not a right friend. As a result, adolescents adopt perceptions about inappropriate sexual relations (Barbaree \& Langston, 2006). This false perception then is used by adolescents as a moral disengagement to justify sexual abuse (Knox, 20I4).

\section{Lack of religiosity}

The juvenile sex offenders on this study admitted that they rarely worship according to their religion. Although $\mathrm{N}$ and J attended religious-based schools, it turns out that the influence of friends was greater than that of religious dogma. Each parent of participants had tried to get their son to be more diligent in worship. But because of the influence of friends, participants ignored their parent command.

My father told me, shouted, snapped when told me to pray, but I did not pray until I was hit by my father (J)

My father asked me to go to the church, I did not want to. I did not go to the church $(\mathrm{N})$

Religion can be individual guidance to behave. An individual can distinguish between good and bad. Religion can prevent an individual from hurting others. Lack of religiosity encourages individuals to commit bad deeds and harm others (Salas-wright, Michael, \& Maynard, 20I3). An individual does not have guidance on how to behave or individuals ignore the norm of religion and society. The important thing is they enjoy it. When their behavior goes wrong, they will 
make a reason. They use moral disengagement to reduce guilty feelings. The level of individual religiosity does correlate with the level of individual moral disengagement (Qudsyi, Nurtjahjo, Afsari, Fitriani, \& Sholeh, 2018).

\section{Permissive environment}

A permissive environment makes teenagers ignore the morals that forbid fornication. The environment, where participants lived, tended to be permissive to an extramarital sexual relationship. For example, participant $\mathrm{R}$ engaged his first sexual intercourse at an internet rental place. The guard of that place let sexual intercourse happened in his internet rental place. Participant E did sexual abuse at a boarding house. Presumably, the boarding house host did not carry out strict supervision. So the boarding house's residents can do sexual harassment quite easily. Near the house of participant $\mathrm{N}$, there was a square. There were many lodging around the square. Many adults and young people had extramarital sex at those lodging. Actually, society knows that immoral behavior, but they just let it go.

Yeah, right there, I seduced my girlfriend to have sex there in the internet rental. The internet rental's guard knew some people had sex there, but he just shut up. So, it was free, and internet rental was free. $(R)$

My father's friend also likes to have sex with girls. He did it at lodging around the square, near my house. I knew it, and he also knew that I also did it (N)

My friend invited me to his boarding house. There is a young woman in his room. Then we drank alcohol together. We were drunk...then it happened $(E)$

Actually, these phenomena were contrary to the prevailing norms in Indonesian society. The norm of society and religion still prohibit extramarital sexual. But it seems, at this time, some people were becoming increasingly permissive. Some people were becoming unwillingly to reprimand those who had extramarital sex. In certain groups of society in Indonesia, there was a growing free relationship between men and women. Participants lived in this kind of environment. Participants saw these phenomena every single day. They adopted these values. So, when participants did fornication to a girl, they also did not feel guilty. They thought It was 
okay to have extramarital sex because many people did it. It was a kind of moral disengagement.

So, such social models made individuals unable to distinguish between what can be done and what not to do (Clark, 20I4). Plus, low social control of society made individuals commit sexual abuse without feeling guilty (Wahid \& Irfan, 20II). So, the environment that was not conducive becomes a bridge to learn antisocial behavior through moral disengagement (Hyde, Shaw, \& Moilanen, 2010) including for the juvenile sex offenders (Barbaree \& Marshal, 2006; Page \& Pina, $2015)$.

\section{Exposure to pornography}

One of the causes of the juvenile sex offenders is exposure to pornography. Pornography in online media is now a common thing, but it is dangerous for adolescents especially male. This is because pornography is a media of sexual education that is wrong and has the potential to teach sexual violence (Stanley et al., 2016). Participant $\mathrm{N}$ admitted that he had seen directly his friend did sexual intercourse. The other participants saw the pornographic film through the mass media, especially from the internet.

"Well, I saw them (having sex), then I was curious. I told them. I once caught you, you naked. Then, they said, it was so good. Yes, it felt good. Yes, then I tried it." $(N)$

"That was, uhm. Since I watched that porn video on the internet, I wanted to keep watching and watching that film again. If you have ever seen a porn video, you would be addicted to watching that video. Like playing video games, if you have ever played a video game, you would keep playing that game, just like that. You don't want to change it”. (A)

The pornographic spectacle prompted participants to commit obscenity. Exposure to pornography can indeed increase individual sexual desire, encourage aggression behavior in men and make men more receptive to violence including rape (Macionis, 2009). In social learning theory (Bandura, 1986), a behavior can be learned through observation of the behavior of others. Porn watches both in real life and in the mass media depicting the scene of obscenity can be one means of social learning for teenagers to commit obscenity. This is also reinforced 
by adolescent associations regarding sexual intercourse and violence, the myths in society and the effects of desensitization (Gadd \& Jefferson, 2013). Exposure to pornography results in desensitization. Individuals will regard what is seen as a natural thing (Lo, Wei, \& Wu, 20I0).

The absence of negative reaction from victim and punishment

The reactions of women who become victims of obscenity affect the minds of juvenile sex offenders. If the victim does not give a negative reaction such as anger or report to the police, the juvenile sex offenders will think that what he has done is something normal. That thing does not make juvenile sex offenders feel guilty for his actions. The next impact is the juvenile sex offenders will probably continue to rape other women.

But, that was okay... I came home from work and it was nothing from my neighbors ... my neighbor was not angry to me ... yes ... ... I did not think there was any business with $w$ anymore, it had been already done, I thought that was normal ...... then I did not think anymore ... (A)

The juvenile sex offenders interpreted the absence of punishment as a sign that the fornication was a normal thing. The fornication was an acceptable action, even for the victim. This finding was consistent with previous studies that, when victims did not show anger, individuals who are sexually abused will assume that victims were happy to be abused (Page \& Pina, 20I5).

There is no ivory that is not cracked. This proverb illustrates that this research has a limitation. This research only focused on external factors as factors that establish moral disengagement of juvenile sex offenders. The internal factor can also affect moral disengagement. Thus, the result of this study has not been able to describe the factors of moral disengagement on juvenile sex offenders as a whole. Those are external and internal factors.

There are several suggestions, according to the result of this study. Juvenile sex offenders can follow the cognitive-behavioral counseling model. Through this cognitive-behavioral counseling, juvenile sex offenders can replace the previous belief with the new one that more in line with 
moral and religious values. In addition, through this cognitive-behavioral counseling, juvenile sex offenders can learn to be more responsible for their actions. Thus, juvenile sex offenders can eliminate moral disengagement.

The government or school can also develop a psychoeducation program for teenagers. This program's aim is to prevent adolescents from doing the sexual crime. This program should emphasize the cognitive element. So that, the adolescent can consider rationally based on moral and religious values when individual face with conflict moral situation.

The last suggestion is for parents. An adolescent is still the responsibility of parents. Therefore, parents should create a conducive environment for adolescents. A parent also should more pay attention to adolescents. The adolescent still needs parental behavior that can be used as an example.

\section{Conclusion}

The finding of this study, in general, supported Bandura's theory of moral disengagement. Juvenile sex offenders engaged in the process of moral disengagement. They reinterpreted their immoral behavior in purpose to reduce their feelings of guilt. However, there were additional forms of moral disengagement that were different from the original theories of disengagement morality. Also, in this study, there was an extension of the notions or indicators of the distortion of consequences.

The moral forms of disengagement perpetrated by the juvenile sex offenders in this study were moral justification, euphemistic labeling, displacement of responsibility, diffusion of responsibility, distortion of consequences, dehumanization, and attribution of blame. These forms were in accordance with Bandura's original theory. The new form of moral disengagement that was found in this study was active avoidance. 
In the distortion of consequences, there was also an extension of the indicator. The juvenile sex offenders perceived his actions as a reciprocal behavior that is equally gaining pleasure. He could fulfill his sexual need while the victim felt happy because they had been bought food and drink. The juvenile sex offenders also perceived that his immoral action was acceptable because there were no negative consequences or protests from victims.

The other result of this study that moral disengagement in juvenile offenders was formed from some social environments. These social environments were peer group, lack of family attention, permissive environment, lack of religiosity, exposure to pornography, and the Absence of negative reaction from victim and punishment.

\section{Acknowledgment}

First, authors acknowledge support from the Directorate of Higher Education (DIKTI) through PDD Grant (Doctoral Dissertation Research Grant) 2018.

\section{References}

Arslan, M. M., Demirkiran, D. S., Ramazan, A., Zeren, C., \& Kokacya, M. H. (2016). General Characteristics of Child Sexual Offenders in Hatay, Turkey. The Eurasian Journal of Medicine, 48, 6-9. https://doi.org/I0.5I52/eurasianjmed.2015.154

Bandura, A. (1986). Social Foundation of Thought and Action: A Social Cognitive Theory. New Jersey: Prentice-Hall.

Bandura, A. (1990). Selective Activation and Disengagement of Moral Control. Journal of Social Issues, Vol., 46(I), 27-46.

Bandura, A. (2002). Selective Moral Disengagement in the Exercise of Moral Agency. Journal of Moral Education, 3 I (2). https://doi.org/I0.1080/03057240220I4322

Bandura, A. (2004). The Role of Selective Moral Disengagement in Terrorism and Counterterrorism. In F. M. Mogahaddam \& A. Marsella (Eds.), Understanding Terrorism; 
Psychological roots, consequences, and intervention (pP. I2I-150). Washington, DC: American Psychological Association Press.

Bandura, A. (2016). Moral Disengagement: How People Do Harm and Live with Themselves. New York: Worth Publisher.

Bandura, A., Barbaranelli, C., \& Caprara, G. V. (1996). Mechanisms of Moral Disengagement in the Exercise of Moral Agency, Journal of Personal and Social Psychology.7I(2), 364-374.

Barbaree, H. ., \& Langston, C.. (2006). The Effect of Child Sexual Abuse and Family Environment. In H.. Barbaree \& W. L. Marshal (Eds.), The juvenile sex offenders (2nd ed., Pp. 58-76). New York: The Guilford Press.

Barbaree, H. ., \& Marshal, W. L. (2006). An Introduction to The juvenile sex offenders: Terms, Concept, and Definition. In H.. Barbaree \& W. L. Marshal (Eds.), The juvenile sex offenders (2nd ed., pp. I-18). New York: The Guilford Press.

Beech, A. R., Ward, T., \& Fisher, D. (2006). The Identification of Sexual and Violent Motivations in Men Who Assault Women: Implication for Treatment. Journal of Interpersonal Violence, 2I(I2), I635-I653. https://doi.org/I0.II77/0886260506294242

Beyer, F., Sidarus, N., Bonicalzi, S., \& Haggard, P. (2016). Beyond self-serving bias: diffusion of responsibility reduces a sense of agency and outcome monitoring. University College London. Retrieved from http://creativecommons.org/licenses/by/4.0/)

Bleakley, A., Hennessy, M., Fishbein, M., \& Jordan, A. (20II). Using the Integrative Model to Explain How Exposure to Sexual Media Content Influences Adolescent Sexual Behavior. Health Education \& Behavior, 38(5), 530-540. https://doi.org/I0.I I 77/I090 I 98I I0385775

Bowes-Sperry, L., \& O'Leary-Kelly, a. M. (2014). To Act or Not To Act: The Dilemma Observers Harassment Faced by Sexual. Academy of Management Review, 30(2), 288-306. https://doi.org/I0.5465/AMR.2005.16387886

Brahmana, K. M. B., Suryanto, \& Bagong, S. (2018). The Dynamic of Gender Role Conflict of Pastors' Husbands at Batak Karo Protestant Church. Journal of Educational, Health, and Community Psychology, 7(I), 38-60. https://doi.org/10.12928/jehcp.v7i2.870I

Caravita, S. C. S., Sijtsema, J. J., Rambaran, J. A., \& Gini, G. (20I4). Peer influences on moral disengagement in late childhood and early adolescence. Journal of Youth and Adolescence, 43(2), 193-207. https://doi.org/I0.1007/s 10964-013-9953-I 
Carroll, J. A. (2009). Impact of Moral Judgement and Moral Disengagement on Rape-Supportive Attitudes in College Males. The University of Alabama.

Clark, J. N. (20/4). Ethnopolitics: Formerly Global Review of Ethnopolitics Making Sense of Wartime Rape: A Multi- causal and Multi-level Analysis, University College London, 374I. https://doi.org//0.1080/I7449057.2014.92846I

Darfiyanti, D., \& Putra, M. G. B. A. (20I2). Pemujaan Terhadap Idola Pop Sebagai Dasar Intimate Relationship pada Dewasa Awal: Sebuah Studi Kasus. Jurnal Psikologi Kepribadian Dan Sosial, I(2), 53-60.

Davids, O., Londt, M., \& Wilson, L. (20I5). Imprisoned Sex Offenders' Chronic Denial and their Childhood Family Environment. The Open Family Studies Journal. 7(I), 42-47.

DeLisi, M., Peters, D. J., Dansby, T., Vaughn, M. G., Shook, J. J., \& Hochstetler, a. (20|4). Dynamics of Psychopathy and Moral Disengagement in the Etiology of Crime. Youth Violence and Juvenile Justice, I2(4), 295-3 |4. https://doi.org/ I0. I 177/ I54 I 2040 I 35069 I 9

Dhingra, K., Debowska, A., Sharratt, K., Hyland, P., \& Kola-palmer, S. (2015). Psychopathy, Gang Membership, And Moral Disengagement Among Juvenile Offenders. Journal of Criminal Psychology. 5(I), I3-24. http://dx.doi.org/I0.I I08/JCP-II-20I4-00I6

Esiri, O. M. (2016). The Influence of Peer Pressure on Criminal Behaviour. Journal Of Humanities And Social Science (IOSR-JHSS), 2 I (I), 8-14. https://doi.org/I0.9790/0837-2 I I 308I 4

Gadd, D., \& Jefferson, T. (20/3). Kriminologi Psikososial Suatu Pengantar. (T. Wahyu, Ed.). Yogyakarta: Pustaka Pelajar.

Galdi, S., Maass, A., \& Cadinu, M. (2014). Objectifying Media. Psychology of Women Quarterly, 38(3), 398-413. https://doi.org/10.1 I77/0361684313515185

Graca, J., Calheiros, M. M., \& OLiveira, A. (20/4). Moral Disengagement in Harmful but Cherished Food Practices? An Exploration into the Case of Meat. Journal of Agriculture Environment Ethics. https://doi.org/10.1007/s 10806-014-9488-9

Grubb, A., \& Turner, E. (20I2). Aggression and Violent Behavior Attribution of blame in rape cases: A review of the impact of rape myth acceptance, gender role conformity and substance use on victim blaming. Aggression and Violent Behavior, 17(5), 443-452. https://doi.org/10.1016/j.avb.2012.06.002

Haslam, N. (2006). Dehumanization: An Integrative Review. Personality and Social Psychology Review, 10(3), 252-264. 
Hunter, J. A., Figueredo, A. J., Malamuth, N. M., \& Becker, J. V. (2003). The juvenile sex offenders: Toward the development of a typology. Sexual Abuse: Journal of Research and Treatment, I5(I), 27-48. https://doi.org/I0.I023/A:I020663723593

Hyde, L. W., Shaw, D. S., \& Moilanen, K. L. (2010). Developmental precursors of Moral Disengagement and the role of Moral Disengagement in the development of antisocial behavior. Journal of Abnormal Child Psychology, 38(2), 197-209. https://doi.org/10.1007/s 10802-009-9358-5

Jewkes, R., Vetten, L., Jina, R., Christofides, N., Sigsworth, R., \& Loots, L. (2012). What we know and what we don't know Single and multiple perpetrator rape in South Africa. SA Crime Quarterly, 4I(September), 247-54.

Kiriakidis, S. P. (2010). Young Offenders' Decisions to Re-offend as A Breakdown of SelfRegulation of Hierarchically Organised Feedback Loops: The Role of Moral Disengagement in Formulating Decisions to Re-offend. European Journal on Criminal Policy and Research, 16(4), 237-250. https://doi.org/10.1007/s 10610-010-9129-4

Kish-Gephart, J., Detert, J., Treviño, L. K., Baker, V., \& Martin, S. (20I4). Situational Moral Disengagement: Can the Effects of Self-Interest be Mitigated? Journal of Business Ethics, I25(2), 267-285. https://doi.org//0.1007/s I055 I-0|3-1909-6

Knox, L. A. (2014). Scholar Attachment and Adolescent Offending: An Examination of the Links between Sexually Abusive Behavior and the Level of Attachment to Parents and Peers. Portland State University. Retrieved from https://pdxsholar.library.pdx.edu/open_access_etds

Leary-kelly, A. M. O., \& Bowes-sperry, L. (200I). Sexual harassment as unethical behavior The role of moral intensity, Academy of Management Review. II, 73-92.

Lo, V., Wei, R., \& Wu, H. (20l0). Examining the first, second and third-person effects of Internet pornography on Taiwanese adolescents: implications for the restriction of pornography, Asian Journal of Communication. 20(I) https://doi.org/10.1080/0I292980903440855

Macionis, J. (2009). Social Problems (3rd ed.). New York: Pearson - Prentice Hall.

McCann, K., \& Lussier, P. (2008). antisocial, Sexual Deviance and Sexual Reoffending in The juvenile sex offenderss Investigation, A Meta-analytical. Youth Violence and Juvenile Justice, 6(4), 363-385. https://doi.org//0.1 I77/I54I204008320260 
McCuish, E., Lussier, P., \& Corrado, R. (2015). Examining Antisocial Behavioral Antecedents of Juvenile Sexual Offenders and Juvenile Non-Sexual Offenders. Sexual Abuse: A Journal of Research and Treatment, 27(4), 4|4-438. https://doi.org/I0.II77/I0790632I35I7268

Naidoo, L., \& Sewpaul, V. (20I4). The Life of experience of adolescent sexual offenders : factors that contribute to offending behaviors. Maatskaplike Werk/Social Work, 50(I), 84-98. https://doi.org// 0.1527056.I-17

Osofsky, M. J., Bandura, A., \& Zimbardo, P. G. (2005). The Role of Moral Disengagement in the Execution Process. Law and Human Behavior, Vol., 29(4), 37I-393. https://doi.org/I0.1007/s 10979-005-4930-I

Page, T. E., \& Pina, A. (2015). Aggression and Violent Behavior Moral disengagement as a selfregulatory process in sexual harassment perpetration at work: A preliminary conceptualization. Aggression and Violent Behavior, 21, 73-84. https://doi.org//0.1016/j.avb.2015.01.004

Page, T. E., \& Pina, A. (2018). Moral disengagement and self-reported harassment proclivity in men: the mediating effects of moral judgment and emotions men : the mediating effects of moral judgment and emotions. Journal of Sexual Aggression, 0(0), I-24. https://doi.org/10.1080/13552600.2018.1440089

Page, T. E., Pina, A., \& Giner-Sorolla, R. (2016). "It was only a harmless banter!" The development and preliminary validation of the moral disengagement in sexual harassment scale. Aggressive Behavior. https://doi.org/10.1002/ab.2162I

Plummer, M., \& Cossins, A. (2018). The Cycle of Abuse: When Victims Become Offenders. Trauma, Violence, and Abuse, 19(3), 286-304. https://doi.org/I0.I I77/I5248380I6659487

Qudsyi, H., Nurtjahjo, F. E., Afsari, N., Fitriani, H. N., \& Sholeh, A. (2018). Spiritual Well - being, Parent Attachment, and Moral Disengagement among College Students. International Journal of Social Science And Humanity, 8(4). https://doi.org/I0.18178/ijssh.2018.8.4.943

Ryan, G. (20/0). Patterns of Affect and Cognition: Dynamic Associated With Behavior. In G. Ryan, T. Leversee, \& S. Lane (Eds.), Juvenile Sexual Offending: Cause, Consequences, and Correction (3rd ed., Pp. IOI-III). Canada: John Wiley and Son.

Salas-wright, C. P., Michael, G., \& Maynard, B. R. (2013). Religiosity and Violence Among Adolescents in the United States: Findings From the National Survey on Drug Use and Health 2006-2010. Journal of Interpersonal Violence, 20(10), I-23. https://doi.org/ 0.1 I 77/08862605 I 3506279 
Sandvik, M., Nesset, M. B., Berg, A., \& Søndenaa, E. (2017). The Voices of Young Sexual Offenders in Norway: A Qualitative Study. Open Journal of Socia Sciences, 5, 82-95. https://doi.org/10.4236/jss.2017.52009

Schuler, S. A. (2014). The relationship between exposure to pornography, victimization history, attachment to parents, and the sexual offense characteristics of adolescents who sexually offend. The University of Toronto.

Seto, M. C., \& Lalumie, M. L. (2010). What Is So Special About Male Adolescent Sexual Offending? A Review and Test of Explanations Through Meta-Analysis. Psychological Bulletin, I36(4), 526-575. https://doi.org//0.1037/a0019700

Shu, L. L., \& Gino, F. (2012). Sweeping dishonesty under the rug: How unethical actions lead to forgetting of moral rules. Journal of Personality and Social Psychology, 102(6), II64-II77. https://doi.org/10.1037/a002838I

Shu, L. L., Gino, F., \& Bazerman, M. H. (20I I). Dishonest deed, clear conscience: when cheating leads to moral disengagement and motivated forgetting. Personality and Social Psychology Bulletin, 37(3), 330-349. https://doi.org/10.1 I77/0146/6721 I398/38

Stanley, N., Barter, C., Wood, M., Aghtaie, N., Larkins, C., Lanau, A., \& Överlien, C. (2016). Pornography, Sexual Coercion and Abuse and Sexting in Young People's Intimate Relationships: A European Study. Journal of Interpersonal Violence, 0886260516633204-. https://doi.org/I0.1 I77/08862605/6633204

Stepanova, E. V. (2017). Alcohol Priming and Attribution of Blame in an Acquaintance Rape Vignette. Journal of Interpersonal Violence. https://doi.org/I 0. I I77/08862605 I 7744762

Stevens, D. L., \& Hardy, S. A. (20I I). Individual, family, and peer predictors of violence among Samoan adolescents. Youth and Society, 45, 428-449.

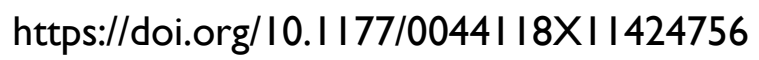

Sweeten, G., Piquero, A. R., \& Steinberg, L. (2013). Age and the Explanation of Crime, Revisited. Journal of Youth and Adolescence, 42(6), 921-938. https://doi.org/10.1007/s 10964-013-9926-4

Wahid, A., \& Irfan, M. (20I I). Perlindungan Terhadap Korban Kekerasan Sexual: Advokasi Atas Hak Asasi Perempuan. Jakarta: PT Refika Aditama.

Wegner, R., Abbey, A., Pierce, J., Pegram, S. E., \& Woerner, J. (20I5). Sexual Assault Perpetrators' Justifications for Their Actions: Relationships to Rape Supportive 


\begin{tabular}{c|l} 
Journal of Educational, Health and Community Psychology & Christanti, \\
$\qquad$ Vol 8, No 4, 2019 E-ISSN 2460-8467 & $\begin{array}{ll}\text { Suryanto, } \\
\text { Putra. }\end{array}$
\end{tabular}

attitudes, Incident Characteristics, and Future Perpetration. Violence Against Women, 2(8), I018-1037. https://doi.org/10.1 I77/1077801215589380

White, J., \& Bandura, A. (2009). Moral disengagement in the corporate world. Accountability in Research. 16. https://doi.org//0.1080/08989620802689847

Wood, W., Quinn, J. M., \& Kashy, D. A. (2002). Habits in Everyday Life : Thought, Emotion, and Action. Journal of Personality and Social Psychology, 83(6), 128I-1297. https://doi.org//0.1037//0022-35|4.83.6.128I 